Bangladesh J. Bot. 44(3): 429-436, 2015 (September)

\title{
DURIO TANJUNGPURENSIS (MALVACEAE), A NEW SPECIES AND ITS ONE NEW VARIETY FROM WEST KALIMANTAN, INDONESIA
}

\author{
Zidni Ilman Navia and Tatik Chikmawati* \\ Department of Biology, Bogor Agricultural University, Darmaga Campus, \\ Bogor, 16680, Indonesia
}

Key words: Durio tanjungpurensis, D. tanjungpurensis var. tembaganensis, D. testudinarum, new species, new variety, West Kalimantan

\begin{abstract}
A new species and a new variety of Durio Adanson from West Kalimantan are described namely, Durio tanjungpurensis Z.I. Navia, sp. nov. and $D$. tanjungpurensis var. tembaganensis Navia, var. nov. The new species has small fruits $(5-8 \mathrm{~cm}$ in diam), brown to yellowish green pericarp, milky white thin aril $(<1 \mathrm{~mm})$, and not edible. It is related to D. testudinarum Becc. Durio tanjungpurensis varies in its flower and fruit characters. The new variety differed from $D$. tanjungpurensis Z.I. Navia, sp. nov. in six characters, i.e. leaf ovate, petal oblanceolate with apex round, fruits on the branches, on the stem, at the base of trunk, no-spine area in fruit apex, pericarp green to yellowish green, aril only $20-40 \%$ covering the seeds.
\end{abstract}

\section{Introduction}

Durio Adanson (1958) is the largest genus in the Family Malvaceae (Nyffeler and Baum 2001) comprising of 30 species which are confined to the tropics of Southeast Asia. Its centre of distribution is Borneo Island, Indonesia, and 21 species of which 15 are endemic. Further, 11 species are distributed in Malaya, 8 species in Sumatra, and one species in each in Myanmar (Burma) and Srilanka (Kostermans 1958, Uji 2005, Mansur 2007). The genus Durio is characterized by five diagnostic features, i.e. a densely lepidote or stellate indumentum on the lower side of the leaves on young branches, and various part of the flowers; a cup-shaped calyx; rather large, showy flowers with generally whitish or reddish petals; anthers consisting of clusters of globular or elongate pollen locules which open either via an apical pore or a longitudinal slit; and big spiny fruits with large seeds that are covered with a fleshy or, in some species, rather leathery aril (Nyffeler and Baum 2001). Eight Durio species have edible fruits including D. zibethinus Murr., D. kutejensis (Hassk.) Becc., D. graveolens Becc., D. dulcis Becc., D. oxleyanus Griff., D. testudinarum Becc., D. lowianus Scort. ex King, and D. grandiflorus (Mast.) Kosterm. et Soeg. (Soegeng 1962, Salma 2011).

\section{Materials and Methods}

In a recent taxonomic study of Durio, survey for specimen collection was conducted in 10 districts of West Kalimantan, Indonesia, namely Mempawah, Landak, Bengkayang, Sanggau, Sekadau, Sintang, Kapuas Hulu, Melawi, Kayong Utara and Ketapang. The survey uncovered occurrence of a new species in two districs i.e., Sekadau and Kapuas Hulu. This species is very similar to D. testudinarum Becc.

After a number of literature study (Bakhuizen van den Brink 1924, Kostermans and Soegeng 1958, Kostermans 1958, Salma 2011) and examinations carried out on a number of specimens, it is concluded that these plants actually represent one new species namely, Durio tanjungpurensis Z.I. Navia, sp. nov. and a new variety namely Durio tanjungpurensis var. tembaganensis Navia, var. nov.

*Author for correspondence: <tchikmawati@yahoo.com>. 


\section{Results and Discussion}

As the newly reported species Durio tanjungpurensis has some similarity with $D$. testudinarum, a compariosn of characters has been presented in Table 1. From Table 1 it is observed that $D$. tanjungpurensis differs distinctly from $D$. testudinarum Becc over six diagnostic characters and the species hitherto described as a new species of the Genus Durio. A taxonomic detail of the newly described species has been furnished below.

Table 1. Morphological comparison of D. testudinarum and D. tanjungpurensis.

\begin{tabular}{lll}
\hline Characters & D. testudinarum & D. tanjungpurensis \\
\hline Aril & $2-3 \mathrm{~mm}$, consumed & $<1 \mathrm{~mm}$ \\
Colour of aril & White to yellow & Milky white \\
Favour of aril & Sweet and watery & Plain \\
Colour of fruit & Yellowish-brown to brownish-green & Yellowish-green to dark brown \\
Bud apex & Pointed and curved & Round \\
Status & Cultivated & Wild \\
\hline
\end{tabular}

Durio tanjungpurensis Z.I. Navia, sp. nov.

(Figs 1, 2)

Diagnosis: Durio tanjungpurensis est morphologia similis ad D. testudinarum, sed it habet parvus fructus $(5-8 \mathrm{~cm}$ in diam), brunneus pericarpium, lactaneus arillus tenues $(<1 \mathrm{~mm})$, et it est fructus est non edibilis.

Durio tanjungpurensis is morphologically similar to D. testudinarum, but it has small fruit ( $5-8 \mathrm{~cm}$ in diam), brown pericarp, milky white thin aril $(<1 \mathrm{~mm})$, and its fruit is not edible.

Holotypus: West Kalimantan Provence: Sekadau Regency, Rawak Subdistrict, Rawak forest, 009'15.8'S - 11051'14.8”'E, 45 meter a.s.1., April 2013, Z.I. Navia 25.

Tree, 10 - $20 \mathrm{~m}$ tall, $14-32 \mathrm{~cm}$ in diam. Outer bark brown to dark brown; inner bark red brown. Sapwood white. Leaves simple, alternate; petiole 10- $23 \mathrm{~mm}$ long; leaf blade thinly to thickly leathery, oblong to elliptic, obovate lanceolate, $12-44 \times 3-12.5 \mathrm{~cm}$; base acute to round; apex acuminate, long acuminate, caudate, acumen about 5-20 mm long; upper surface glabrous, midrib and primary nerves sunken; lower surface densely covered with tightly appressed, midrib strongly prominent, lateral nerves parallel, reticulation inconspicuous. Inflorescences solitary or 2 - 5 flowers clustered in a group on the trunk, at the base of trunk; flower buds green to greenish yellow, ellipsoid, $2-3 \times 1-2 \mathrm{~cm}$, apex acute to round; pedicel $3-5.5 \mathrm{~cm}$ long; epicalix persistent, splitting into 2 equal, ovate, $2-3.5 \times 1.5-2.5 \mathrm{~cm}$, outside densely scaly, inside stellate-hairy; calyx 5, free, green, ovate, apex acute, $2-3 \times 1-1.5 \mathrm{~cm}$, outside scaly, inside glabrous with dense stellate hairs at the base; petal 5, free, white, oblong, apex round to acute, $5.6-7.5 \times 1-1.5 \mathrm{~cm}$, outside dense stellate hairs, thickened at middle of base; stamens whitish yellow, shorter than the corolla, upper 5 - $10 \mathrm{~mm}$ of phalanges; filaments free, slender, bearing each with 10 reniform anthers in a globose clump; anthers opening by a slit; ovary densely covered with scales; stigma yellow, capitate, 5-lobed, glabrous. Fruit on the trunk, at the base of trunk, oblate to globose, lobed; 6.7 - $7.8 \mathrm{~cm}$ in diam.; spines conical and pyramidal, 5 - $11 \mathrm{~mm}$ long; aril very thin $<1 \mathrm{~mm}$, aril milky white. 

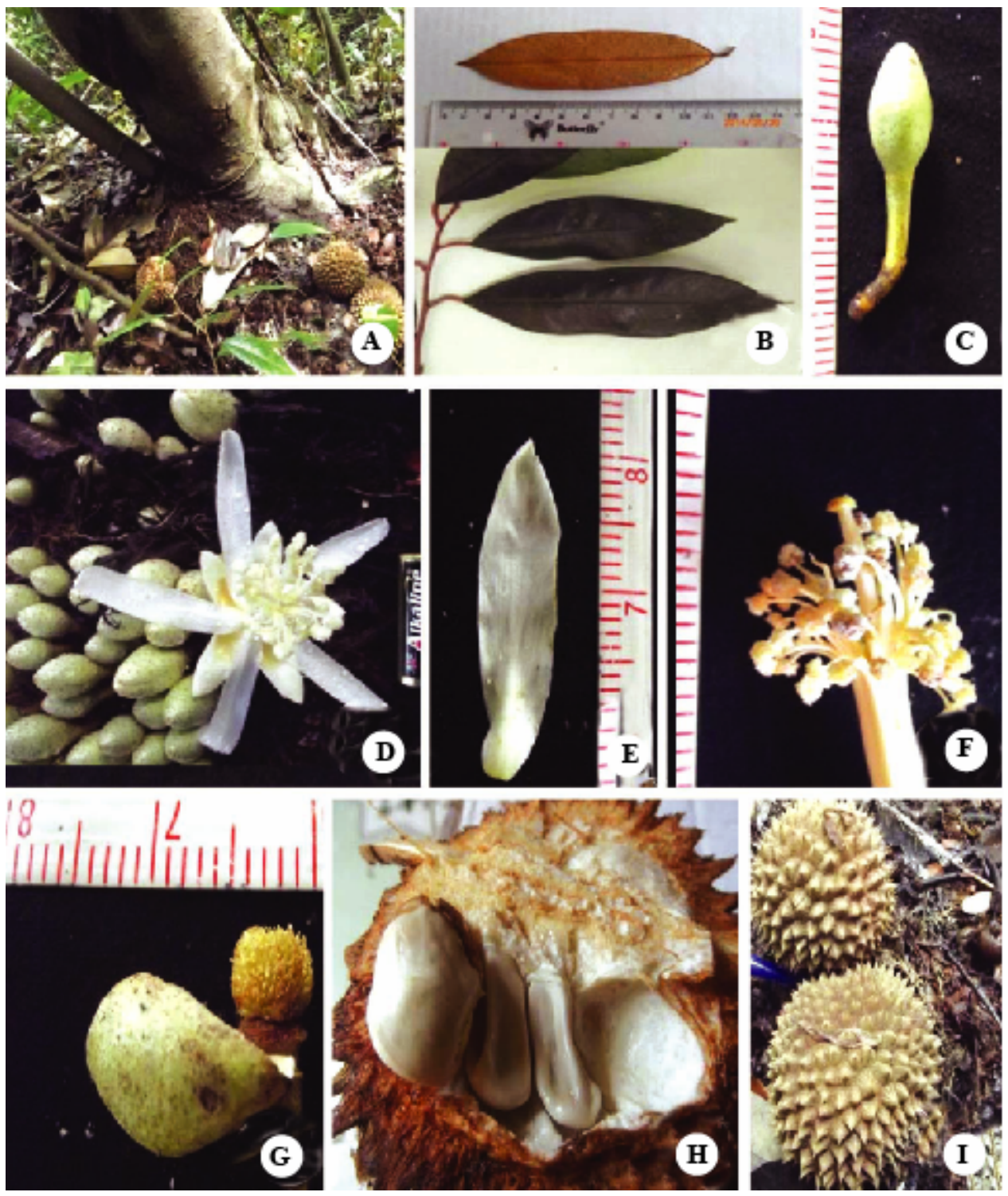

Fig. 1. Durio tanjungpurensis sp. nov. A. Tree and fruits, B. Leaves, C. Bud, D. Flowers and buds, E. Bud, F. Anther and stigma, G. Ovary covered with scales, H. Aril milky white, I. Fruits at the base of trunk and above ground level.

Phenology: Flowering in May - September, Fruiting in November - December.

Distribution and habitat: Durio tanjungpurensis had been found in five locations in West Kalimantan, that were Rawak forest, Rejunak forest, Merindang Hill, Tembaga forest and Sagu Hill. It grows in mixed Dipterocarp forest, customary forest communities, near plantation; associated to Artocarpus, D. griffithii, D. kutejensis, D. oxleyanus, D. zibethinus, Hevea braziliensis, Lithocarpus, Shorea, Ficus, Nepenthes, Rattan, Pandanaceae. 


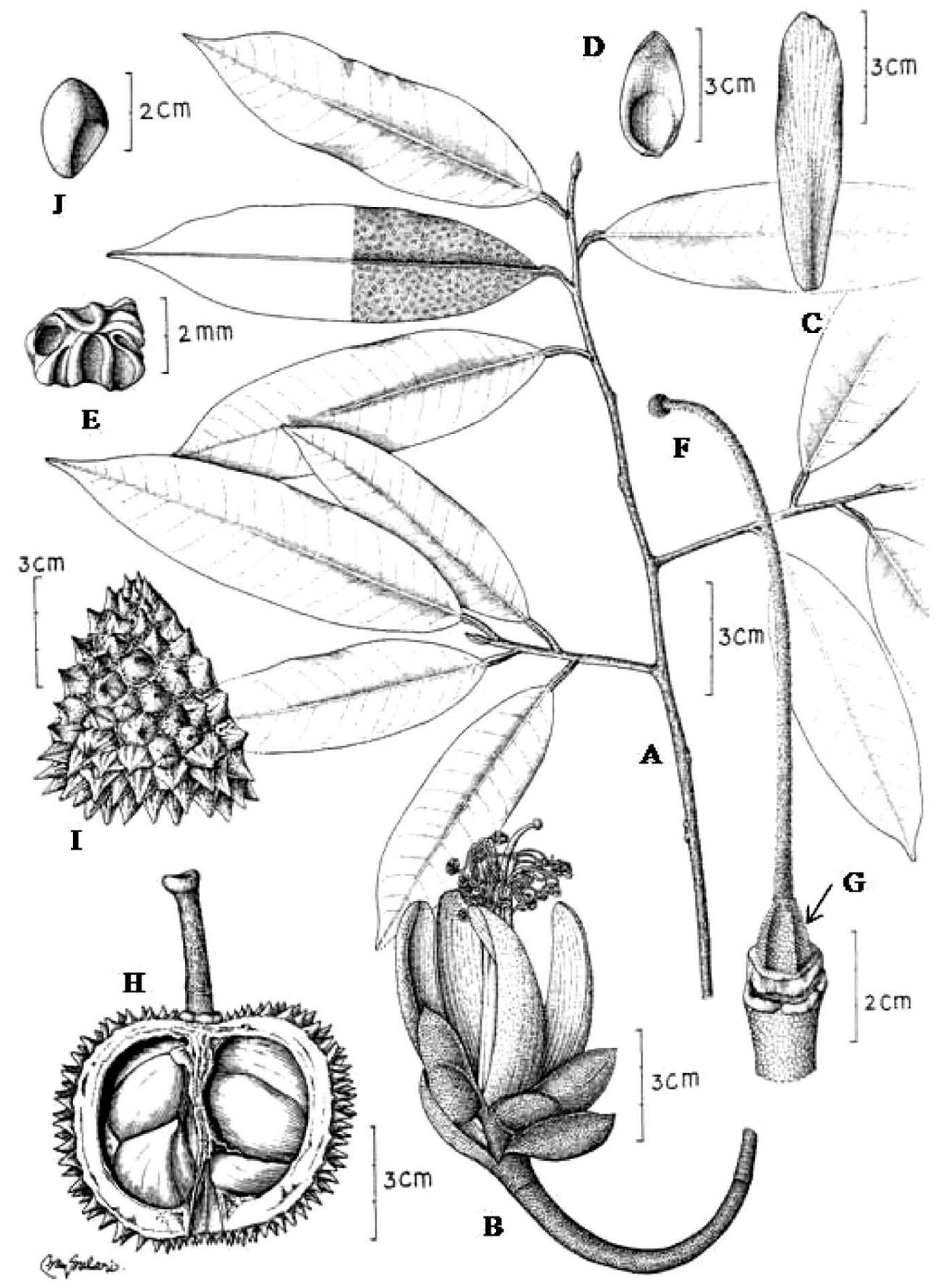

Fig. 2. Illustration of Durio tanjungpurensis sp. nov. A. Leaves, B. Flower, C. Petal, D. Anther, E. Pistil, G. Ovary, H.fruit, I. Fruit apex with spines. 
Taxonomic relationships: Durio tanjungpurensis is morphologically similar to $D$. testudinarum Becc. It has leaf oblong; leaf apex acuminate to long acuminate, base acute, rounded to cordate, and has fruit on the base of trunk.

Etymology: Named after the type locality, West Kalimantan

Additional specimen examined: INDONESIA. West Kalimantan Province, Sekadau Regency, Nanga Mahap, Tembaga forest, Z.I. Navia 01, Z.I. Navia 02, Z.I. Navia 03, Z.I. Navia 04, Z.I. Navia 05, Z.I. Navia 06, Z.I. Navia 07, Z.I. Navia 08; Nanga Engkulun Subdistrict, Merindang Hill, Z.I. Navia 09, Z.I. Navia 10, Z.I. Navia 11, Z.I. Navia 12, Z.I. Navia 13, Z.I. Navia 14; Rawak Subdistrict, Rejunak forest, Z.I. Navia 16, Z.I. Navia 17, Z.I. Navia 18, Z.I. Navia 19, Z.I. Navia 20, Z.I. Navia 21, Z.I. Navia 22, Z.I. Navia 23; Rawak forest, Z.I. Navia 25, Z.I. Navia 26, Z.I. Navia 27; Kapuas Hulu Regency, Nanga Silat Subdistrict, Sagu Hill, Z.I. Navia 28, Z.I. Navia 29, Z.I. Navia 30, Z.I. Navia 31, Z.I. Navia 32, Z.I. Navia 33, Z.I. Navia 34, Z.I. Navia 35.

Note: There is variation in flower and aril, shape, size and color of fruit among the specimens of D. tanjungpurensis. The first group of specimens grows flowers and fruits at the base of trunk, fruits with brown pericarp and aril completely covering the seeds. The author named the first group as var. tanjungpurensis. The second group has flowers and fruits on the branches, at the base of stem and at the base of thrunk, green pericarp, aril very thin only $20-40 \%$ covering the seeds. The author named the second group as var. tembaganensis var. nov.

\section{Key to varieties}

Petal oblong, fruits brown pericarp, conical spines, aril completely covering the seed

var. tanjungpurensis

Petal oblanceolate, fruits green to yellowish green pericarp, pyramidal spines, aril $20-40 \%$ covering the seeds

var. tembaganensis var. nov

\section{Durio tanjungpurensis var. tanjungpurensis}

(Figs 3, 4)

Holotype: West Kalimantan Provence: Sekadau Regency, Rawak Subdistrict, Rawak forest, 0099'15.8”'S - 11051'14.8”E, 45 meter a.s.l., April 2013, Z.I. Navia 25.

Petiole $10-23 \mathrm{~mm}$ long; Leaf thinly to thickly leathery; oblong to elliptic, obovatelanceolate, $12-44 \times 3-12,5 \mathrm{~cm}$; petal oblong, apex acute to round; fruit on the trunk, at the base of trunk, oblate to globose, lobed; brown pericarp until ripe; $6.7-7.8 \mathrm{~cm}$ diam.; spines conical, 5 - $11 \mathrm{~mm}$ long; aril very thin $<1 \mathrm{~mm}$, milky white aril, covered seed completely.

Distribution: it has been found in four locations in West Kalimantan, that are Rawak forest, Rejunak forest, Merindang Hill, and Sagu Hill.

Durio tanjungpurensis var. tembaganensis Navia, var. nov.

(Fig. 2)

Diagnosis: Foliis ovatus, petalum oblanceolatus cum apex rotundus; fructus in ramiflorus, in caulibus, ad basim e truncus, spineless area in fructus apex grandis, pericarpium viride to flavovireus, arillus $20-40 \%$ tegens at semen.

Holotype: West Kalimantan Provence: Sekadau Regency, Nanga Mahap Subdistrict, Tembaga forest, $0^{\circ} 30^{\prime} 37.4^{\prime \prime}$ - $-110^{\circ} 40^{\prime} 48.9^{\prime \prime}$ E, 93 meter a.s.l., April 2013, Z.I. Navia 04.

Leaves ovate; petal oblanceolate with apex round; fruits on the branches, on the stem, at the base of trunk, no-spine area in fruit apex large, pericarp green to yellowish green, aril $20-40 \%$ covering the seeds. 

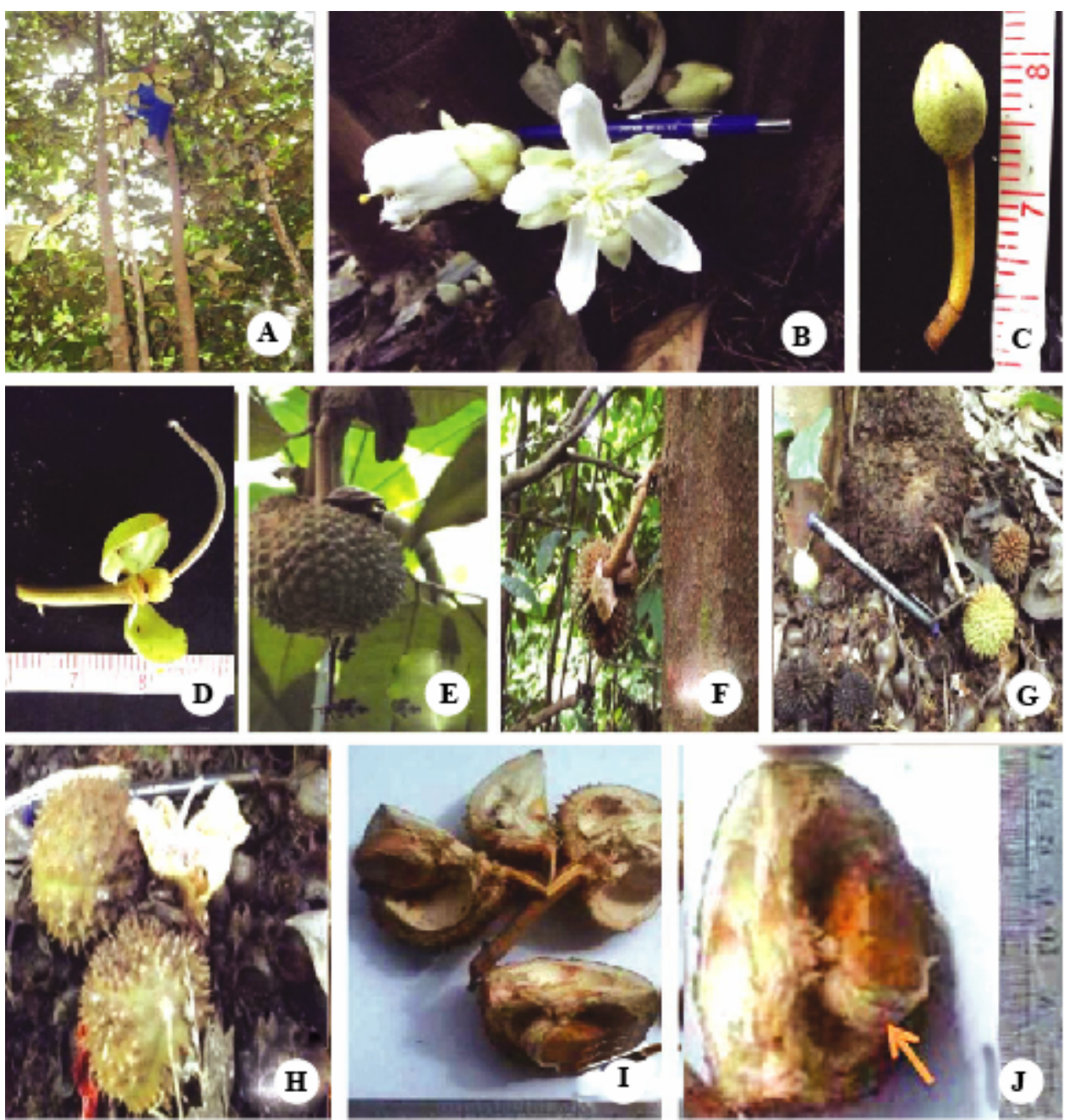

Fig. 3. Durio tanjungpurensis var. tembaganensis var. nov. A. Tree, B. Flowers, C. Bud with apex rounded,

D. Pistil, E-G. Fruits on the branches, on the stem and at the base of trunk, H. Fruit apex without spines.

I-J. Fruit with aril not completely covering the seed.

Petiole 11 - $13 \mathrm{~mm}$ long; Leves thinly; oblong to elliptic, ovate, $12-44 \times 3-12,5 \mathrm{~cm}$; petal oblanceolate, apex round, $6.6-7.7 \times 1.2-1.5 \mathrm{~cm}$; fruit on the branches, on the stem, at the base of trunk, globose, lobed; pericarp green to yellowish green; $6.3-7.8 \mathrm{~cm}$ diam.; spines pyramidal, $3-5 \mathrm{~mm}$ long, no-spine area in fruit apex large, aril very thin, aril milky white, aril $20-40 \%$ covering the seeds.

Distribution and habitat: Durio tanjungpurensis var. tembaganensis var. nov has been found only in one location, Tembaga forest in West Kalimantan. It grows in mixed Dipterocarp forest, customary forest communities, near plantation society; associated to Artocarpus, D. kutejensis, $D$. oxleyanus, D. zibethinus, Hevea braziliensis, Lithocarpus, Shorea, Ficus, Rattan, Pandanaceae. 


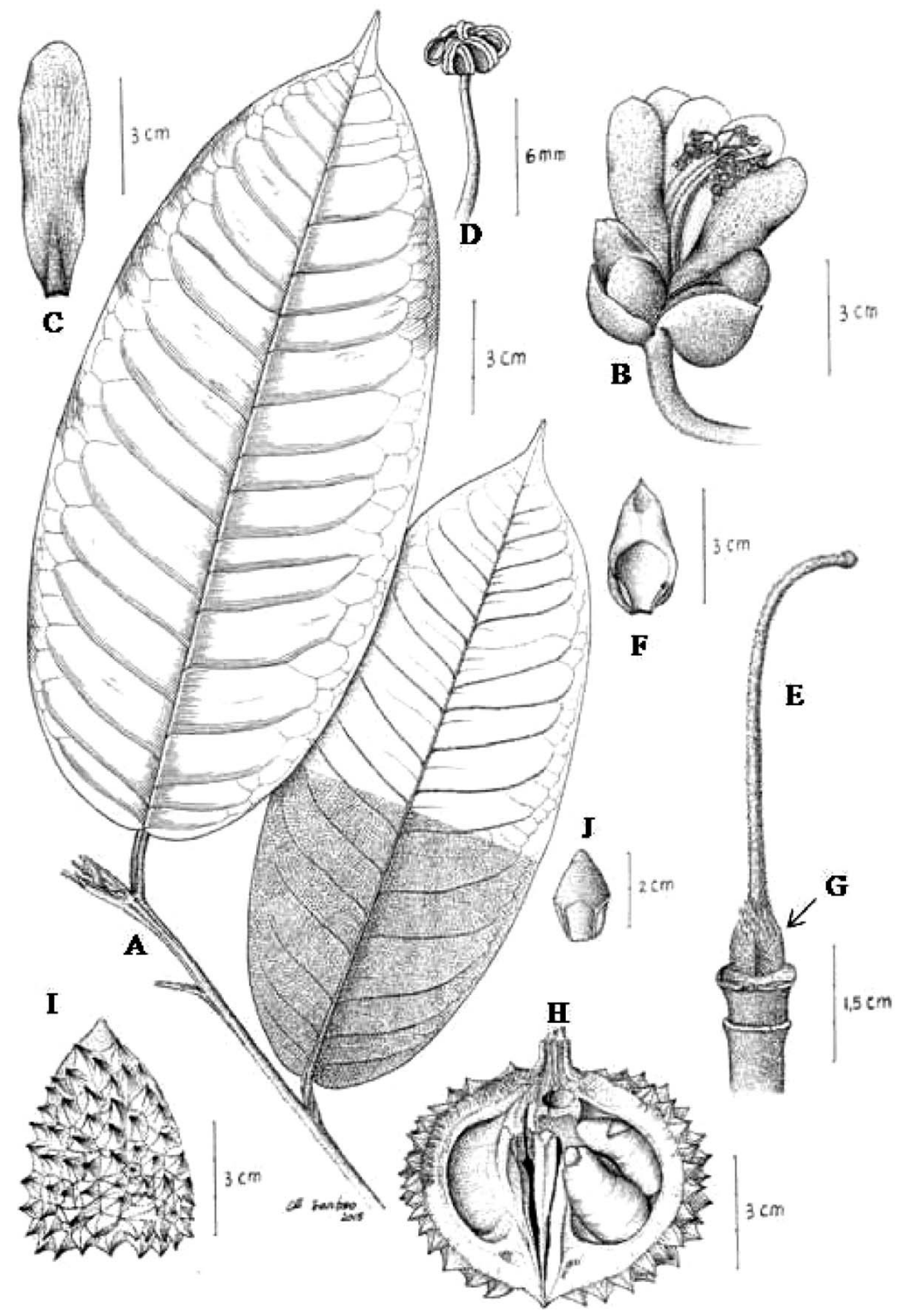

Fig. 4. Illustration of Durio tanjungpurensis var. tembaganensis var. nov. A. Leaves, B. Flower, C. Petal,

D. Anther, E. Pistil, F. Sepal, G. Ovary, H. Fruit, I. Fruit apex without spines.

\section{Acknowledgements}

The authors are thankful to Prof. Mien A. Rifai for his guidance and advice during this research. Thanks are due also to Adi Bejo Suwardi, M.Si for his assistance during exploration in the study area. 


\section{References}

Bakhuizen van den Brink RC 1924. Revisio Bombacaceae. Bulletin J. Bot. Buitenzorg, Series III 6(2): 162$163,223-225$.

Kostermans AJGH 1958. The genus Durio Adans. (Bombacaceae). Reinwardtia 4(3): 47-153.

Kostermans AJGH, Soegeng WR 1958. A monograph of the Genus Durio. Commun. For. Res. Inst. Bogor 61: $1-51$

Mansur M 2007 Penelitian ekologi jenis-jenis durian (Durio spp.) di desa Intuh Lingau Kalimantan Timur. J. Tek Ling 8(3): 211-216.

Nyffeler R, Baum DA 2001. Systematics and character evolution in Durio s. lat. (Malvaceae/Helicteroideae/ Durioneae or Bombacaceae-Durioneae). Organisms Divers. Evol. 1: 165-178.

Salma I 2011. Durio of Malaysia. Mardi, Malaysia. pp. 117-125.

Soegeng WR 1962, The species of Durio with edible fruits, Economy Bot. 16: 270-282

Uji T 2005. Keanekaragaman jenis dan sumber plasma nutfah Durio (Durio spp.) di Indonesia. Buletin Plasma Nutfah. 11: 28-33.

(Manuscript received on 3 March, 2015; revised on 11 May, 2015) 